\title{
The Pragmatarian Style
}

\author{
Environmental Change, Global Health, and Gro Harlem \\ Brundtland's Nordic Internationalism
}

SIMON REID-HENRY

\subsection{Introduction}

In this chapter I examine the internationalism of Norway's former prime minister, and one of its most successful internationalists, Gro Harlem Brundtland. This chapter suggests that during the 1980s and 1990s Brundtland pursued a distinctive form of pragmatic humanitarianism in her efforts to influence the international agenda. The distinctiveness of this approach emerges during her two main appearances on the world stage: first in her role as head of the World Commission on Environment and Development (1983-1987), where I suggest she brought a distinctly Nordic brand of humanitarian internationalism to the emergent environmental politics of the time; and second, through a reconsideration of her role as Director General of the World Health Organization (1998-2003) and the reform program she oversaw there. The argument I make is that, across these two moments - resulting, respectively, in the birth of a new concept and the realization of a new institutional arrangement - it becomes possible to observe the workings of a distinctive style of international politics that we might term "pragmatarian."

By pragmatarian I mean an approach to "doing good" in the world that combined altruism with a willingness to compromise on humanitarian idealism in the name of political realism (something particularly strongly ingrained in the social democratic mind). In that sense the pragmatarian style, as it emerged to address some of the pressing social and environmental problems coalescing through globalization in the early 1980s, was part ethical imperative and part contingent practice of globalization itself, bound together in a distinctive political form. But this was more than just the self-conscious deployment or working out of a political brand (Moisio et al. 2011; de Bengy Puyvallée 2018). In his 1964 
essay, The Paranoid Style in American Politics, Richard Hofstadter examined the historical development of what he called a "style of mind" in American domestic politics. The conspiratorial framework of Hofstadter's analysis is a long way from someone like Brundtland's brand of solidarism, and US domestic politics are not the international realm. But as coherent political styles the paranoid and the pragmatarian share certain traits in common. Above all they each conform to the observation that a political "[s]tyle," as Hofstadter (1964a: 5) noted, "has more to do with the way in which ideas are believed than with the truth or falsity of their content" [my emphasis].

In developing his argument Hofstadter borrowed loosely from clinical psychology. My aim here is to borrow loosely from his political insights in turn, and to suggest that paranoia need not be the only psychological or social basis of a given "style" in politics. What prompted the paranoid style, for Hofstadter, was a sense of dispossession: be it earlier incarnations in the nineteenth century, which saw illuminism, masonry, and Catholicism as threats to an imagined prelapsarian image of American life; or the mid-twentieth century form that most interested Hofstadter, which was animated by what US conservatives in those years perceived as the national treachery committed by immigrants, cosmopolitans, communists, and the intellectuals who for many conservatives combined those various traits. Transposing Hofstadter's analysis to the later twentieth century, a very different provocation could be said to give rise to the pragmatarian style, and this time it is one to which social democrats, rather than conservatives, were prone. This was the sense of disempowerment that social democrats felt before the great structural forces of economic development that were wreaking havoc, from the 1970s onwards, at the international scale (Ferguson et al. 2010; Reid-Henry 2019).

After all, more than any other ideological grouping, social democrats had appeared to be able to tame these forces nationally. Yet with globalization emergent they roiled still at the international level. In place of conspiracy and betrayal, then, we find for social democrats in the later twentieth century a newfound powerlessness. In both cases it is a sense of political and intellectual awe before the scale of a newly discovered problem that animates the political style. In a way that Hofstadter does not fully explore, we might go so far as to say that these political styles emerge, in other words, when there is a prevailing sense among protagonists that something like such a style has to emerge: and that only by acting in conformity with such a style is redemption of the prior political identity (or "brand") a possibility. Here the similarities end. For where 
the paranoid style is conservative, the pragmatarian style is progressive, and where the former developed in the real world as it "mixed its fortunes with American party politics" in the mid-twentieth century, the latter enfolded itself within the international bureaucracy of the late twentieth century (Hofstadter 1964a: 22). There, in place of treason as the favoured enemy motif, one finds instead the moral vacillation and ignorance of mankind at large: waiting to be fixed, as we shall see, by the technocrats and the doyens of market signalling.

Of course, much of what I have said about pragmatarianism thus far could just as easily be lain at the feet of do-gooding humanitarianism writ large: consider the crusading style of a Bernard Kouchner and his Médicins Sans Frontières, for example. But like its conservative American counterpart, the pragmatarian style has a more specific purpose than change per se: It seeks not just social improvement (or even social activism) but rationally and energetically to convert that desire for change into a common-sense framework, and to insist that political and institutional reform only makes sense from within the uncontestable logic of such a framework. The marshalling of evidence - not simply the use of evidence, or even necessarily its veracity in the case of the paranoid style, but rather its calculated political presentation and display - is key, in both styles, to the mobilization of such reforms. Again, however, there are important differences between them. In place of a black and white world view and a militant puritanism (two traits that strongly shaped the paranoid style), the pragmatarian sees complexity and takes compromise to be a political virtue. Where the paranoid style "all but obsessively" (Hofstadter 1964a: 36) accumulates evidence precisely so as to avoid the give and take of open political debate - to "ward off the profane intrusion of the secular political world" as Hofstadter (1964b: np) put it in the Harper's version of his essay - the pragmatarian style deploys evidence precisely in order to politicize. What unites them however, and warrants their consideration alike as political styles, is the fact that each seeks these ends not merely in order to bring about change but to redeem some fundamental mistake undertaken by others. Its proponents are thus by contrast the "elect," the sitters on panels (like Gro herself in her later engagements with The Elders), the committee members and figureheads of global commissions. It is here that each style may ultimately come to be a matter of belief, rather than ideology or moral commitment. And it is this that perhaps also encourages adherents of such a style to subvert their own critique: be it the conservative demagogue abusing the law to fight perceived infringements of the 
law, or the pragmatarian turning to the market to circumvent the problems of the market.

As I want to explore in this chapter, Brundtland embodies important elements of this more progressive - yet equally paradoxical - pragmatarian style, and via the two unparalleled opportunities she was afforded to deploy it at the international level (though not, I should stress, in any way self-consciously I think), we are also granted the means to examine the pragmatarian style in action. Though it should be stated that such a style is subconsciously articulated, its traces are hardly invisible. Selfeffacement, it turns out, does not sit any better with the pragmatarian style than it did with the paranoid incantations of Hofstadter's analysis. And the four-time prime minister with "her Harvard degree and her Calvinist roots," as Time Magazine put it, was "seldom apologetic" (Dalton-Bradford 2000: 113; Gibbs 2001). Yet there can be no denying that Brundtland's politics also conformed to an underlying attitude of beneficence, even "noblesse oblige," likely stemming from her training as a doctor. And despite frequent comparisons to Margaret Thatcher (often simply because they were both female prime ministers) she was no ideologue. She was far more "a coalition builder" (Henderson 2013: 76), which is further indication of the extent to which her political world view was unified more by a certain style than a rigid ideological framework. In Brundtland's world view, in other words, one finds that to "do good" one first and above all has to "do."

Brundtland's sense of higher obligation was further shaped - unusually so, for a rich world head of state at the time - by her "astute comprehension of the necessity of global solutions" (Dalton-Bradford 2000: 114). Her husband was a scholar of international relations, and this may have reinforced the fact. Gro was anyway ahead of her time in seeking to normalize a commitment to international solidarity among the citizens of the advanced industrial economies (in contrast to the moral exceptionalism preached by the likes of the Live Aid concert at the time). As one of her staunchest critics, fellow Norwegian politician Carl I. Hagen of the Freedom and Progress Party once put it of the Norwegian nation under her prime ministership: "We are world champions at solving other countries' problems ... We behave as though we are a superpower" (cited in Gibbs 2001). It may be fair to say, indeed, that it was "solving problems" that animated Brundtland more than her predilection for social activism per se. To see solutions where others see only bottlenecks, and to be committed, moreover, to advocating on behalf of those solutions, as if possessing some "special authority" to do so (Hofstadter 
1964a: 35); to want to speak in fact on behalf of mostly imagined communities - the "global poor" being no less a work of political fiction, after all, than Nixon's "silent majority" - these traits, too, fit well the definition of a political "style."

The pragmatarian style, as I seek to describe it here, thus trades in part on the self-proclaimed neutrality of the "altruistic" identity of the "Nordic brand," but allies this - in the manner outlined above - with a pragmatic political vision for its fulfilment. The motivation for the pragmatarian style, and its particular resonance in a Nordic context, was in this sense identified somewhat earlier by a rather different Nordic internationalist, Gunnar Myrdal. For Myrdal, writing in the 1950s and the 1960s, the challenge of internationalism was precisely to scale up the political insights (and associated institutional architecture) of national social democracy. If not, he warned, the result would be "mere" humanitarianism internationally (Reid-Henry 2017). In many ways Myrdal was proven right after the upheavals of the 1970s and the failure, in particular, of the vision of the non-aligned countries for a new international economic order based upon cooperative multilateralism. And yet in Brundtland's two internationalist moments, we see a genuine attempt to adhere to that prior social democratic impetus and to put its insights to work internationally.

In order to contextualize the emergence of the pragmatarian style through Brundtland's two principal acts on the international scene both also need to be set against the wider backdrop of an emergent "global" public opinion, economic globalization (specifically in its post-NIEO form) and the closing of the Cold War. For while a style may be articulated by individuals, it requires social changes to take root in the world: "[C]ertain historical catastrophes or frustrations may be conducive to the release of such psychic energies, and to situations in which they can more readily be built into mass movements or political parties," as Hofstadter (1964b: np) puts it. The upheavals of 1970s - the oil shocks, stagflation, the political crises and mass social movements of the age provided just such a context for pragmatarians in the late cold war years. But it is equally necessary to contextualize this political style in relation to the Nordic roots of Brundtland's own approach to international politics. The emergence of the pragmatarian style suggests a more practical alternative identity to the "moral superpower" brand of the Nordic nations as explored elsewhere in this volume.

For a country such as Norway, the pragmatarian style as embodied by Gro Harlem Brundtland offered, most basically, a means for a small 
nation to reassert itself in an era of emerging powers and acute geopolitical crises. By hitching Nordic diplomacy to the institutions of liberal internationalism and the techniques of market globalization, Norway was able to maintain its status as an important international actor. Today, at a time when multilateralism is said to be in crisis and when Norway's traditional "peace" brand has been challenged through its engagements in Afghanistan in particular (and more recently still via Jens Stoltenberg and its leadership ties with NATO), as well as by its diplomatic scuffles with China over the award of the Peace Prize to Chinese dissident Liu Xiaobo in 2010, the pragmatarian style is again proving popular as a basis upon which to refashion the Nordic brand: well embodied, for example, by the recent UiO-Harvard-Lancet Commission on Global Governance for Health (2011-). Indeed, the whole trope of "global governance" rather nicely articulates core aspects of the pragmatarian style. And there may also be lessons here for those governance agendas that, like the pragmatarian style and the paranoid style before it, ultimately propose solutions so askance from the underlying causes that the problems which first animated them are unlikely to ever be reformed out of existence (not least since, to do so, would be to deprive the style's adherents of a cause).

In what follows I cannot hope to address all of these issues. Instead my aim is simply to sketch out the emergence and development of the pragmatarian style. My account begins with the launching of Norway's then young female prime minister Gro Harlem Brundtland upon the international scene in 1983. That year, in what was the most substantial international act of her career so far, Brundtland was selected, from among a list of candidates that included former US President Jimmy Carter, to chair a new World Commission on Environment and Development (WCED) recently formed by the UN to address growing concerns over the environment. Contrary to most accounts of the work of the Commission in the literature, in the first part of this chapter I set out to understand the WCED as a "site" where the pragmatarian approach to international politics can be seen emerging. This is not without reward: doing so in fact helps us to resolve one of the principal conundrums of the WCED and its legacy, namely how a process which initially cleaved to a quite radical agenda ended up providing one of the late twentieth-century's most powerful bulwarks against committed social action on the environment. This "lost" radicalism of the WCED can now be accounted for, since it was in keeping with the pragmatarian style that the Commission's initial embrace of a political account of the problem of climate change could be reworked into the distinctly more 
values-based solution that the WCED ultimately bequeathed to the world: the ur-concept of "sustainable development." Such a move not only helped to shape the outcome and the legacy of the WCED for the environmental movement going forward. It also transformed the nature of liberal humanitarian internationalism more broadly: opening up a new path for addressing structural problems via market logics and instruments, giving succour (whether intentionally or not) to the idea that efficiency-maximization offered the best way to tackle large-scale challenges arising out of globalization, and that global-scale political change in turn required the mobilization not of solidarity but of self-interest. The pragmatarian style made each of these fundamental contradictions seem like practical steps towards a robust and doable solution.

It is Brundtland's second act on the international scene which allows us to confirm this thesis and to map the ongoing development of the pragmatarian style over time. This later reprise came about through her election to the position of Director General of the World Health Organization in 1998, shortly after her prime ministership in Norway had ended. By now the thrust of Nordic internationalism more broadly was geared to the institutions of a post-Cold War liberal order. Free of the constraints of the Cold War - and its formerly precarious position bordering the USSR - Norwegian internationalism in the 1990s more actively adopted the ostensibly de-politicized and "solutions-oriented" approach to international diplomacy that Brundtland had in some senses tested at the WCED. Aid and development were now no longer an adjunct to Norwegian diplomacy as abstract goals or moral imperatives; rather, they were an important channel of diplomacy in their own right. Here, as I try to show in the second part of the chapter, is where a more mature form of pragmatarianism found its niche. Brundtland's efforts to transform the World Health Organization can again be shown to articulate elements of the pragmatarian political style, whose core now consisted in mapping onto the international domain the ideal of equality of opportunity emerging out of the "new" social democracy of the 1990s, with its echoes of "third way" managerialism and poverty reduction as a more depoliticized way of addressing inequality and the sources of social and economic injustice. The outcome of this later variant of pragmatarianism was not a new concept, as above, but this time the elaboration of a managerial technique. Translated to the context of the WHO this meant ensuring that the WHO's vast global bureaucracy was streamlined, primarily so as not to get in the way of new entrepreneurial initiatives that could assist the poor, and in which the pragmatarians placed the bulk of 
their faith. The resistance to her reforms that Brundtland encountered at the WHO equally well represented the limits to this more mature variant of the pragmatarian style. Setting these two elements together (the birth of a concept and the elaboration of a technique) thus also allows us to reconceive the history of two touchstone moments in the history of Nordic internationalism. Perhaps above all, it allows us to reconceptualize the Brundtland Commission and the restructuring of the WHO in the 1990s as two overlooked stepping-stones on a path - the pragmatarian path - from the structural radicalism of the NIEO to the neoliberal individualism of contemporary global governance and rights-based approaches to development.

\subsection{Act I: The WCED (1983-1987) - A New Nordic Internationalism Is Born}

Our first act opens at the World Commission on Environment and Development (WCED). When the United Nations under then Secretary General Pérez-Cuellar initiated the idea of a global environmental commission in the early 1980s, it was responding to the first great wave of ecological concerns that had arisen during the 1970s. Such concerns had led to the rallies and marches attending the launching of the first Earth Day on April 22, 1970, while the era's ecological fears had long since been ignited by books such as Rachel Carson's bestselling Silent Spring (1962) and concerns about runaway population growth articulated in Anne and Paul Erlich's The Population Bomb (1968). These were also the years that brought us the first vistas of the Earth afloat in space, captured in photos like Earth Rise (1968) and broadcast widely around the world. When this first-generation environmentalism burst onto the political scene at the start of the 1970s it took two distinctive forms. On the one hand was a brand of alarmism variously linked to millennialist and "alternative" lifestyles. This reached its apogee in reports such as 1972s Club of Rome report, Limits to Growth. On the other was a more state-oriented party-political movement that treated the environment as a stake in wider (mostly western) social struggles (Du Pisani 2007: 89-90). From out of the Club of Rome report, came a third path forward, however, and this was one that held out a promise of redemption with respect to the other two: the potential role of technology in meeting socio-economic needs without doing undue damage to the environment. This was echoed in the Stockholm conference of 1972, chaired by future WCED member Maurice Strong, which began to float the idea of a more "sustainable" 
path to development (Thacher 1992; Smith 2005: 78). The central debate at Stockholm was whether technology would worsen or alleviate the global environmental situation, and at decade's end experts were still divided on the matter. With inflation and spiking oil prices, the public meanwhile had become increasingly concerned about the rising cost of living, which only further underscored the scale of what it would cost to address these burgeoning global scale environmental concerns.

The launch of the World Commission on Environment and Development (UN General Assembly Resolution 38/161 of 1983) sought to resolve some of these as yet unanswered environmental questions by linking them to heightened concerns about the state of the macro-economy and the fate of heavily indebted poorer nations within it. Via its shift in scale to the global, the WCED would chart the path of sustainable development as an antidote to the more localist "limits to growth" (Carruthers 2001: 98; Smith 2005: 78). Gro Harlem Brundtland was appointed to head up the Commission in 1983. Brundtland had been in office for a little over eight months in 1981, but she brought with her the experience of her stint as Minister of Environment in Norway from 1974 to 1979. Moreover her selection conformed to a certain global common sense at the time regarding the status and standing of Nordic internationalism, coming as it did on the heels of two prior, Scandinavian-inflected "commissions": the Brandt Report (1980, the Commission on International Development) and the Palme Report (1982, the Commission on Disarmament and Security). The Brundtland Commission, as the work of the WCED would become known, ultimately overshadowed both of these prior reports. This was not simply on account of the scale of the UN's ambitions for the WCED (Brundtland's official mandate, from UN Secretary General PérezCuellar, was to construct nothing less than "a global agenda for change"). It was also - as we shall see - because of the way in which Brundtland organized and took control of the work of the Commission itself. It is here that a door onto the pragmatarian style can begin to be cracked open.

Brundtland was joined at the WCED by 22 commissioners from around the world. No sooner had she set about selecting them, than she immediately confronted the two fundamental geopolitical axes that dominated the 1980s: the North-South divide and the East-West tensions of the Cold War. North-South tensions emerged from the start, with northern nations favouring stricter future regulation, and southern nations concerned at the extent to which this would undermine their 
own present development (Borowy 2013: 200). As a female leader Brundtland confronted at the same time a patriarchal political environment (Smith 2005: 94). Alongside Brundtland was appointed Mansour Khalid, Sudan's former Minister of Foreign Affairs, as first Vice Chairman. The two of them, representing different lines of authority over the Commission - Brundtland to Cuellar and the UNGA, and Khalid to the United Nations Environment Program (UNEP), which had hosted an initial conference on the topic in Nairobi in 1982 (and whose Executive Director, Mostafa Tolba, strongly felt that the Commission ought to have been UNEPs to lead). To make matters worse Brundtland and Khalid did not get along (Smith 2005: 82). Such personal tensions would ultimately be kept in check, but conflicting worldviews persisted within the Commission, and one of the southern Commissioners, Pablo Casanova, went so far as to resign his position feeling that the Commission was pursuing primarily a "northern" agenda. East-West tensions made themselves felt as well, not least since the US believed its interests were likely to be threatened by such a Commission, while the USSR was more than a touch suspicious: the Soviets providing Russian commissioner, Vladimir Sokolov, with a KGB assistant up until around late 1985 (Borowy 2014: 68). Solving the riddle of how to meet the twin goals of environmental protection and economic growth simultaneously thus meant, in practice, that the commission would need to secure points of view from across the north-south and east-west divides of the time, analyze that information in real time, condense any findings into concrete policy objectives, and then advocate on behalf of its conclusions to a distinctly sceptical global audience.

With its inaugural meeting held in October 1984, and the Report itself due in the fall of 1987, the Commission would also need to do all this within three years. As Brundtland herself recalled: "Our mission was more a matter of politics in general than of traditional environmental protection" (Brundtland 2002: 197). For all that the WCED initially looked set to follow the pattern of the Brandt and Palme Commissions before it, therefore, the WCED in fact soon veered on to an altogether different path. Brundtland, it was clear, wanted to make sure that things got done, and to this end one of her first acts as Chair was to appoint the experienced Canadian James MacNeill, head of environment at the OECD and former Deputy Environmental Minister in Toronto, as (full-time) Secretary General of the WCED, which now also was afforded rooms in the Palais des Nations as its official base in Geneva. MacNeill was an obvious choice for the role. It was he who had helped set the ball 
rolling for the WCED in Nairobi in 1982 and his work on environment and economics at the OECD in many ways provided the intellectual framing for the entire Commission's work (it was also a source, in its own right, of pragmatarian thinking). He was joined by Warren Lindner of the World Wildlife Fund as head of administration. Lindner too was given a clear steer as to how the Commission was going to work. Of Lindner's interview Brundtland recalled, "The American heard a great deal that day in Oslo, about Scandinavian concepts of democracy and leadership, and about the style I call my own" (Brundtland 2002: 197).

At this stage of proceedings that style involved consultation with all stakeholders (something Brundtland practiced during her various stints as prime minister as well) and an emphasis on collecting evidence couched in the inclusive principles of Nordic democracy. This way of approaching the Commission's work was shared by Lindner and MacNeill in particular (Montgomery 2016). Hence for all its global ambitions and entanglements the Commission articulated from the start as well a distinctly Scandinavian organizational culture and style. The WCEDs wider institutional parameters further supported such an approach. Four of the eight governments that committed to financing the Commission during its four years of work (Denmark, Finland, Norway, and Sweden) were Nordic nations. Three of the most critical figures of the 22-person Commission were familiar from before with Nordic political and developmental thinking: James MacNeill himself was half-Swedish and had studied for his masters in Stockholm (1951) and he was assisted by several Norwegian advisors; Mansour Khalid, for all he otherwise differed from Brundtland, had toured Scandinavian countries in 1971 seeking funds from development NGOs to assist in the resettlement of Southern Sudanese refugees; and then, of course, there was Brundtland herself.

Brundtland was critical in determining both the consensus-based manner of the Commission's work, but also its ultimate legacy. To begin with Brundtland was committed to trying to resolve the paradox of how to combat poverty and ecological destruction at the same time: she genuinely sought change for the better and was one of the earliest heads of state to fully grasp the full implications of the environment question. But for all she would oversee Norway's official development assistance rising from 0.7 to 1.0 per cent, she was not, in the manner of a Raúl Prebisch, seeking major structural reforms. Moreover the international context for the Commission's work involved tackling head on some of the most basic questions of economic development at a time when the 
third world debt crisis was reaching its height. The latter would increasingly come to preoccupy the Commission: culminating in a dramatic showdown at its final meeting in Japan. Brundtland's later comment "Norwegian political values were well represented by the WCED report" (Brundtland 2002: 268) - needs evaluating in this light. For as against the oft-cited "neutral" or "humane" nature of the moral agenda that is usually taken to be the Nordic brand's central feature, Brundtland's management of the WCED increasingly in fact gave vent to a distinctly results-oriented approach which began to push those classic Nordic concerns that problems of global welfare needed addressing as political problems above all, towards a form of diplomatic triage that could be aided by recourse to the mobilizational power of market signalling.

In the Canadian literature the Commission's work has accordingly been cited as an example of "pragmatic idealism" (Melakopides 1998). Perhaps the primary register of this is to be found in Brundtland's own instance that the environment should never be considered separate to questions of development. A commonplace today, this was innovative in its time. But it was a reduction of the commission's initial commitment to the belief that economic growth, social equity, and environmental sustainability all went hand in hand - if managed properly. At the core of the intellectual case that the Commission initially began to explore, was thus a relational analysis of the nature of world poverty that tied the state of the environment to economic growth and which structured both domains as distinctively political problems. This much was radical, but following on from that analysis was a further constant invocation throughout the meetings to focus on the "practical" - as in Oslo, where the minutes of discussions report a debate on science and technology, wherein: "The discussion on this subject illustrated that science and technology has a tendency to become philosophical and it was therefore suggested that the Commission should address the practical implications of science and technology." Ultimately it was the latter practical approach which won out. In so doing it altered what was perhaps the single most radical component of the WCED: its commitment to organizing itself around a series of revolving public hearings and stakeholder submissions (WCED 1988: 2).

The idea to organize the Commission around a central spine of global public hearings was MacNeill's and at first garnered a mixed response.

\footnotetext{
${ }^{1}$ Minutes of the 3rd Meeting Oslo June 1985 - WCED_v40_doc28, p. 15. My emphasis.
} 
As one historian puts it: the suggestion provoked scepticism among some of the Commission members and outright irritation around the world. Few countries of the world were open democracies where such events could have been considered normal. Many governments, including those of countries of origin of most commissioners, were bound to react with suspicion, creating the question of whether to prioritize governmental sensitivities or broad interchanges with people who were affected by the issues being discussed. But the role of public hearings became central to the operation of the WCED and the ability to host them in turn became a central prerequisite to actually hosting one of the six meetings in any given city (Borowy 2014: 66-69). During the hearings, literally "[h] undreds of organizations and individuals gave testimony ... and over 500 written submissions constituting more than 10,000 pages of material were received by the Commission in connection with them" (Melakopides 1998: 155). ${ }^{2}$ The iterative nature of this process proved significant to the outcome of the WCED, not least since the Commission's final report was written all the while and so absorbed these changes in thinking along the way.

The length and intensity of these "deliberative meetings" varied, however. While usually they took place for around 3-4 days (as in Indonesia, Norway, Brazil, Zimbabwe, Kenya, the Soviet Union, and Japan) they lasted for over a week in Canada (Melakopides 1998). The quality of the "public" varied as well. Prior to the Sao Paulo meeting the hearings tended to be quite carefully convened by host states in dialogue with commission members. But still, commitment to a form of deliberation was real and meaningful and the hearings helped the Commission to "transcend national boundaries and disparate cultures." Brundtland herself placed a good deal of emphasis on the ideas emerging from them, though it is less clear whether they in fact unearthed anything unexpected. As Borowy suggests (2014: 70), what the hearings ultimately provided was testimony and, over time, a clear sense of the pervasiveness of certain types of problems. Their real contribution, then, was to provide a common language otherwise missing at the start of the process, and through which the otherwise very differently positioned commissioners could engage one another in generating a distinctive set of arguments.

2 See also annex 2 of the Brundtland Report: "At its Inaugural Meeting, the Commission also decided that its processes would be open, visible, and participatory and that in conducting its work, strategies would be employed to ensure it of receiving the broadest range of views and advice on the key issues it was addressing." 
This became apparent after the fourth meeting, in Sao Paolo. In the context of the recent fall of the military dictatorship in Brazil, the arrival of the WCED with its call for open public debate was welcomed in that country as a breath of fresh air. As a result the meetings were inundated with citizens and community groups, as on the final day when, by all accounts, the audience seemed reluctant to let the new wind of open public debate blow out. From Sao Paolo the Commission moved on to Ottawa, where the relationship between these public inputs and the outputs of the Commission's own work began to shift, as the pragmatarian style took over. In stark contrast to the noisily peopled character of the Sao Paolo meeting, for example, the post-Ottawa drafts onwards reveal the language of Sustainable Development in formation - as the Commission moved away from concrete matters of environment and development into a more abstract mode. This was no doubt necessary to keep the Commission's transformative ambitions in play diplomatically. But it meant that at the same time as there was possibly even a growing radicalism to some individual commissioners' private interpretations of the problem (as some came to see that all meaningful change required changes in rich countries as well as in the global South), the public presentation of the Commission's work was more carefully toned down. The Commission had by now acknowledged, in other words, that it would not be able to state its views explicitly. As Nitin Desai, one of the Commission's many advisors observed after Ottawa, "the note [coming out of this meeting] glossed over the challenges of dealing with discounting the future and with uncertainty" (cited in Borowy 2014: 63).

The breakthrough for the pragmatarian style in the context of the WCED's work came in December 1986, when the Commission arrived in Moscow just eight months after the Chernobyl disaster. The Committee was now at its "conclusion" stage (Brundtland 2002: 208). But how could a global commission on the state of the environment not take a stand on a disaster on the scale of Chernobyl (for all that the true scale of Chernobyl was not, it is true, yet known to the world)? Moscow thus confronted the Commission with its own inherent paradoxes: for while it confirmed the Commission's instincts that matters of the environment were increasingly shot through with politics, it also nourished an interpretation of that problem which was projected out of the prior assumptions of the pragmatarian style, and which supported a very different solution: the idea that sustainable development (that is a vision of social and environmental entropy balanced by capitalist economic growth) was 
"apolitical" when, in reality, it was every bit as political as the state socialist managerialism which had resulted in Chernobyl (cf. Sachs 2000: 34).

To be sure, Chernobyl was raised by the Commissioners in Moscow, and preemptively addressed in the Soviet delegation's welcome and opening remarks. But the topic was largely airbrushed throughout. The most revealing exchange occurred when, on the afternoon session of December 11, MacNeill asked A. S. Timoshenko, a member of the legal panel of the Commission, directly what he thought, in light of Chernobyl and other transboundary ecological crises, international law should do to avoid a similar catastrophe. Timoshenko's answer is in effect no answer at all. "[L]aw should basically follow events not prevent them," he says. "Well whether it is good or bad as far as environmental protection is concerned it is bad, but it is objective reality which reflects the conditions under which we all living." 3 This lack of political will to which Timoshenko alluded, but also and perhaps less consciously reinscribed, was the nub of the problem here. And one wonders whether, at this stage, with even the force of Chernobyl at their back, the Commissioners had simply come to accept that the best one could do was to provide a language in which change might be debated rather than create the framework for change itself.

The public birth of the concept of sustainable development, as it was finally articulated coming out of the last meeting in Tokyo just a couple of months later, thus needs understanding less as a breakthrough in ecological thinking, and more as a breakthrough for the pragmatarian style itself. This is not to criticize the concept out of hand. If much of the advice of the Brundtland Commission has gone unheeded this is hardly the fault of the Commission itself. Sustainable Development is today one of the most widespread public policy discourses: compare the lack of influence of the Carnegie Commission on Preventing Deadly Conflict, for example (Pederson 2005: 273). It has become a developmental "buzzword." Yet arguably its status today owes less to what it offered in practical policy terms and more to the fact that it provided a means of depoliticizing the politics of environmental change at the moment of that movement's mainstream emergence: "the world has vanished into the earth" in Sachs' (2000: 127) memorable verdict. The Commission, after all, had begun its work adamant that it was inequities in the world system

${ }^{3}$ Moscow Public Hearings, Afternoon Session December 11 Transcript, p. 160: 0041P/cm/ $\mathrm{PH} /$ Moscow/Tape 6. 
that were driving ecosystem destruction and the uneven apportionment of the effects of this. Yet it concluded, through its promotion of the idea of sustainable development, and despite two years of public testimony largely supporting its original and more radical analysis, that further economic growth was the best solution for resolving the problems of economic growth. Sustainable development was thus itself mostly a solution to the political problem of reconciling the antagonistic positions of the Commissioners and their respective world views - those "contending intellectual streams ... and tensions exposed at Stockholm and later UN conferences," as one scholar has put it (Dierwechter 2018: 55). Perhaps, too, it was the first example of post-Cold War capitalist triumphalism occasioned by the death of alternative approaches in Moscow. The geopolitical tensions that the Commission began with were in any case, in a practical sense at least, not so much resolved as simply incorporated by its end.

Sustainable development thus enabled the WCED, with Brundtland at its helm, to reformulate the terms of its original mandate. The problem had been reduced in scope and the Committee, on those terms, appeared to have succeeded in its task. The Commission's final Report, Our Common Future, was launched to a media fanfare in London in April 1987 (WCED [1987] 2009). Tellingly, and of a piece with the pragmatarian style, no actual objectives or procedures were outlined (Linnerid 2017: np). Equally in keeping with the pragmatarian style, the central concept of sustainable development itself was framed less as a technical description - something which immediately antagonized critics (e.g. O'Riordan 1988) - and more as a way of "framing" the problem: simplified, asserted, and somewhat stripped of its political history.

Our Common Future was presented to the UN General Assembly in October in New York. By then Chernobyl and the Ozone layer were each topics of widespread conversation the world over, allowing the concept of "sustainable development" to be received as the necessary reform that capitalism needed to continue its onward march, while state socialism was already writing itself out of the picture. A UN general resolution (42/ 187) committed states to considering the recommendations of the report and a centre opened in Geneva to popularize its findings. In due course Our Common Future gave on to the work of Agenda 21 and the Rio Declaration of 1992 and ultimately to the MDGs at the turn of the millennium. But in all of this, something of the report's original radicalism, not least its emphasis on inequality, was lost as the pragmatarian style, through purpose and - as at Moscow - serendipitous intervention, 
gradually emerged. Along this pathway those signs pointing back to the NIEO were written over, and others pointing forwards towards the age of global governance were put up.

The legacy of the WCED thus turned out not to be the legacy that Brundtland herself perhaps initially sought or the impact that the Commission long strove for. This is not Brundtland's fault so much as it is something we can observe taking place around her leadership of the WCED. MacNeill's formulation coming out the Commission, for example, was that public opinion was now "far ahead of governments": more global and more forward looking at the same time. "The politics of greening," as he put it, "will continue to drive the greening of politics well into the twenty-first century" (MacNeill 1990). Yet what the WCED had ultimately shown was that redemptive simplifications could disrupt this sort of political circuitry, as the currents of idealism and efficiency at the heart of the pragmatarian style took a concrete shape in the world of international politics.

This was seen as a victory at the time: Our Common Future was hailed as "the most important document of the decade on the future of the world" (Gerasimova 2017: np). Simply for existing, perhaps that was true. But within just a few years certain of the flaws in the pragmatarian style were already becoming apparent. As the New Internationalist captured well in a 1992 feature it ran on the legacy of the WCED, indicting the report for its managerialism dressed up as good intentions:

In effect the Brundtland Report incorporated ecological concern into the idea of development by erecting "sustainable development" as a conceptual roof under which the environment could be both violated and healed ... Systems language purges reality of local particularities, of quality and uniqueness ... [it] cannot resist looking at living communities from the standpoint of control. (New Internationalist 1992)

If somewhat acerbic, this was nonetheless a fair description of the outcomes of a political style that was committed above all to ensuring its solutions appealed as widely as possible, even as they moved away from its own original diagnosis of the problem.

\subsection{Act II: The WHO (1996) - Pragmatic Internationalism Enshrined}

In her work leading the WCED, Gro Harlem had been at one centre of the emergence of a pragmatarian style in international politics. 
Her return to the international sphere, at the helm of the World Health Organization (WHO) in 1998, opens up a further window onto that pragmatarian style a decade later. By now not only was the international context substantially different; Brundtland's articulation of the pragmatarian style had also deepened. Brundtland arrived at the WHO at a critical moment. Prior to her appointment, the organization, which had been set up in 1948, was in danger of being eclipsed by other actors, such as the World Bank, which were moving into the health arena (Walt 1993; Ruger 2005). In response the WHO had begun a process of internal reform, officially known as the Response to Global Change working group. Established in 1992, amidst calls for a "radical restructuring" of the WHO (Smith 1995; Godlee 1997: 1359), the working group set out to examine how better to equip the WHO to respond to the emergent "global" challenges of the post-Cold War era: the shift, in effect, from international to global health (Yach and Bettcher 1998; Brown, Cueto and Fee 2006: 69; cf. Clift 2013: 34).

The group reported back the following year. If the WHO was to retain its leading role in the health sector, the report suggested, it needed both to raise its ambitions to a global, rather than regional, level and overhaul its management structure in pursuit of that end (Brown et al. 2006). International health, in other words, needed to follow the path towards the global already lain out by the environment sector. Accordingly, when the WHO looked around for a new Director General to champion this change, one "who could restore credibility to the organization and provide it with a new vision," as Brown et al. (2006: 69) later put it, Gro Harlem Brundtland was in many ways an obvious choice for the role, not least with her experience as both medical doctor, politician, and chair of the WCED.

In canvassing for the post, Brundtland herself placed substantial emphasis on the deep roots of her public service "internationalism" and, of course, her professional understanding of the health sector learned as a practicing doctor in Norway. Although she would this time be dealing not with a small group of Commissioners with strong personalities but with a major international bureaucracy, her approach to health as a policy problem was broadly the same as her approach had been to the environment. She sought to put the WHO firmly on the map by bringing to it a sense of its political mission. She wished, she said, to make it a "department of consequence" (Brown et al. 2006: 70). To do so she linked health improvements to the yardstick of economic growth, just as 
she had linked the economy to the environment before. ${ }^{4}$ To this end Brundtland frequently referred, while at the WHO, to "better health and better economic development," and to "good investments, in terms of health dollars spent" (cited in Davies 2010: 39). This time, however, she was in a position to oversee the means of actually implementing such a vision, rather than simply reporting on it as before. Under her leadership WHO programming would henceforth become more disease-specific, more "vertical," and less focused on health systems in the round (as had been the once-influential vision, back in 1978, of the Alma Ata conference and approach to global health policy). It would partner with a range of "private" actors, such as the Gates Foundation, and was at times accused of being too accommodating of powerful donors.

As a global institution the WHO was duly retrenched around a core mission in Geneva, providing oversight functions of an increasing variety of semi-autonomous (and issue specific) public-private partnership programs. This moved it away - though here Brundtland would encounter resistance - from the regional leadership that had dominated the organization to date, divided as it had been historically into a series of regional sub-organizations (Ruger and Yach 2008). Even more sharply than was the WCED, the WHO was now to be organized in accordance with the basic tenets of the pragmatarian style: with the role of evidence, norms, and efficiency each being emphasized in particular. This time, however, the evidence base for change put forward by Brundtland would be sourced not by public hearings, but through professional (often private) consultancy, by the establishment of a new Evidence for Information and Policy cluster at the WHO, and via the introduction of Disability Adjusted Life Year (DALY) metrics which had begun to be used at the World Bank from 1993 (Homedes 1996) and would be taken up also in the new Global Fund for Aids, TB, and Malaria after 2002. The normative orientation of Brundtland's reforms, by turns, was directed less at "public opinion" and focused instead on changing the actual function of the WHO: strengthening its role as a "norm-coordinator" - in essence a governance function - rather than as the enactor of programs itself. Finally, the efficiency of the reform program would be obtained not by harnessing "growth" in the name of sustainable development (as before) but by arguing for the positive contribution that good health could make to economic growth, via the reduction of political

4 This was undertaken by, inter alia, the formation of the Commission on MacroEconomics. 
bureaucracy, and by amplifying the role of the market in decisionmaking mechanisms within the WHO.

Such changes were institutional in the first instance. But they were again animated by the moral imperative to "do something," one generated this time by a new suite of post-Cold War global health security challenges that had begun to emerge: from HIV/AIDS to Ebola (Lakoff 2016). In many respects it was this that gave the second articulation of the pragmatarian style, as represented by Brundtland's reforms, such traction: enabling in just a few short years a major overhaul of the centrepiece of the global health bureaucracy. Unlike at the WCED, Brundtland and her reformers at the WHO were not leading the charge from out in front: they were supported this time by the political leadership of the G8 countries struck as they too had been (belatedly now, in the mid-late 1990s) by the moral force of HIV/AIDS. This afforded a certain humanitarian impetus to Gro's reform agenda (Lidén 2013), especially when that force was conveyed through the cold logic of numbers. Here an interesting inversion of the paranoid style becomes apparent in the pragmatarian variant. Where Hofstadter (1964a: 35) could observe that, "[o]ne of the impressive things about paranoid literature is the contrast between its fantasied conclusions and the almost touching concern with factuality it invariably shows," the pragmatarian style was interested only in such conclusions as the evidence might support (conclusions reached long after empathy, for example, may have pointed in the same direction).

It would be wrong, of course, to paint the entire reform process at the WHO as the product of pragmatarian thinking. Not least, the desire to transition the WHO from provider of health programs to a normcoordinator, for example, had already been articulated in another influential WHO reform document produced prior to Brundtland's arrival: the UN Nordic Project led by Denmark, Norway, Finland, and Sweden (Clift 2013: 30). Similarly the move away from a structure of powerful and semi-independent regional offices, towards a more centralized executive (and a more executive centre) based in Geneva, was supported by the report of the UN's own Joint Inspection Unit (JIU) of $1993 .{ }^{5}$ What Brundtland's reform process achieved, rather, was to bind each of these ambitions together with the sense of institutional failure emerging from

${ }^{5}$ Joint Inspection Unit, "Decentralization of Organizations within the United Nations System. Part III: The World Health Organization," Geneva, 1993, www.unjiu.org/data/ reports/1993/EN93-02.PDF (cited in Clift 2013: 21). 
that decade's stark confrontation with a new scale of global health security challenges and a set of arguments which encouraged all actors to see that, with the right levers and managerial systems in place, health problems might "clear" just as well-managed markets always would. Taken together the result was a form of the pragmatarian style whose legacy, this time, was not a novel concept (as before) but a deep swerve in the direction of WHO policymaking (a new organizational technique).

What did this new technique look like? In contrast to the Commission-based work of the WCED, leadership of the WHO afforded Gro the opportunity to actually implement a range of policy measures. Within just the first three months, Brundtland had downsized fifty departments into thirty-five and re-organized those that remained according to new strategic priorities (Yamey 2002; Clift 2013). At the top of the organization, the leadership structure of the WHO was overhauled, with the previous Assistant Director General positions replaced by new Executive Director posts given to individuals with technical expertise. Further down the hierarchy she oversaw an increase in the use of public-private partnerships to address the funding inconsistencies at the WHO (though in the view of many critics it also simply transferred the influence that donors had from states and their voluntary contributions to private actors with their self-defined agendas). Alongside this she also championed the turn towards data-driven policymaking, notably within the two signature health programs she introduced: the Tobacco Free Initiative, leading to the Framework Convention on Tobacco Control, and the Roll Back Malaria campaign. To oversee all this work she brought in experts from Harvard to operate a new Evidence and Information policy unit at the WHO, prompting one observer to comment that the WHO was becoming "a branch of Harvard and the World Bank" (cited in Yamey 2002).

There was more than just sour grapes in such a comment. The change in personnel and programs reflected a larger change in priorities and approach. As Brundtland herself put it: "What is our comparative advantage?" Often it seemed that the answer to this was bringing governments and the private sector on board and making the case that good health is good economics. When Our Common Future was launched this approach was widely lauded. The second time around Brundtland encountered more resistance, not least from within the very bureaucracy she was seeking to overhaul. Brundtland had set out to (re)define the WHO's mission in the world not on the basis of an analysis of what the world needed in terms of health provision, but in terms of what a more 
streamlined WHO would be "best" positioned to deliver. It was a subtle, but as Lerer and Matzopoulos (2001) point out, significant difference in approach, and Brundtland even incorporated the "Commission" format within the WHO to bring this about, via her Commission on Macro Economics and Health. As Jeffrey Sachs, the man she appointed to head up the Commission, later put it, what the macro-economic Commission advocated for was a form of "science-based politics" (cited in Clift 2013: 42). In a sense this is what Brundtland successfully introduced across the WHO at large. But with hindsight it becomes easier to see that this was always a very specific politics, focused on the ways in which wealthier nations might demonstrate the terms on which they were willing to help provide global public goods, and thereby underscore their utility to the management of world affairs. It was not obviously in keeping with her vision, "[a]s a social democrat," as she put it at around this same time, to "strive to change society in such a way that it is healthy for people, enhances equality and distributes primary needs in an honest way" (cited in Ribberink 2006: 1).

Alongside her deepening embrace of the pragmatarian style, Brundtland's understanding of international politics had also developed in the years since the WCED. "Fifty-three years of life experience and 18 years of political work in government and the parliament of my country have brought me to the following view of the most fundamental challenges of our time: The forces of technology, of finance, and of electronic communication have increasingly taken over the powers that were vested in democracy to shape our future," she declared to an audience of Ivy League alumni in the US in 1992. "What should be our global village is threatening to turn into a global jungle. We need to replace international anarchy with international governance" (Brundtland 1992: 161). Such a view was afforded a boost in the context of the closing of the Cold War. "The challenge of the 1990s," Brundtland went on "is to deepen and widen the forces of democracy and to lift democratic decision making also to the international level" (Brundtland 1992). Such a view was also, of course, in keeping with arguments made by other liberal internationalists of the era, notably Anne-Marie Slaughter's outline of a "new world order" of multilateral, transboundary governance playing out within and across sectors (such as health and the law) as much as between national sovereign states, and where democracy - public participation - per se was somewhat less prioritized (Slaughter 1997). The appeal of the pragmatarian style extended beyond the particular rendering of it provided by Brundtland. 
At the same time, the challenge at the WHO was a good deal more specific than such rhetoric allows for, and in a way that complicated things for a pragmatarian such as Brundtland. In particular, with her reform agenda, Brundtland had promised to change the way in which the WHO was funded and to restore coordination across its regional offices (two of the most serious problems confronting the organization in the years prior to her arrival under former Director General Nakajima). To be sure, what Brundtland achieved at the WHO was hugely impressive, given the diminished status of the organization when she took over (Yamey 2002). Yet if there were two reforms that eluded Brundtland, when she left the WHO after just a single term in office, it was the need to coordinate the operations of her newly empowered WHO headquarters in Geneva with that of the older regional offices, and to grant - via funding reform - greater decision-making power to the World Health Assembly, which still functions as the only real democratic chamber within the WHO.

This narrowing of the sphere of decision-making agency ultimately demonstrates just in what ways her conformity to the pragmatarian style had changed between her time at the WCED in the 1980s and at the WHO a decade later. What was gained was the post-Cold War globalism of the elites; what was lost was the prior, and distinctly Nordic, notion of democratic inclusivity with which Brundtland had first experimented at the WCED. Perhaps most fundamentally, her initial emphasis on "deliberative" public engagement at the WCED was almost entirely absent at the WHO a decade later, and not just because of the different mandates that she took on at the WCED and the WHO. The enactment of a form of global "town hall" hearing was arguably the greatest innovation coming out of the WCED - certainly as significant as the (ultimately watered down) conception of sustainable development itself. Yet while the latter persisted to influence the work undertaken by Brundtland and her team at the WHO, the deliberative approach did not - and this despite the fact that the WHO itself already had an annual "assembly" that could have fulfilled such a role. The WHO instead saw the centralization of authority around the office of the Director General, one marked by Brundtland's own mantra of there being "One WHO, not two." In the end it was also this that represented the limits to Brundtland's pragmatarian approach to reform of the organization. Her call for a global health politics conjoined to the conflicting imperatives of humanitarianism, efficiency, and technocratic control ultimately fell on deaf ears amongst many at the WHO. Frustrated from within, 
Brundtland never sought re-election as Director General for a second term. International bureaucracies, it seems, can be harder to change than global public opinion.

\subsection{Conclusion: Nordic Legacies of the Pragmatarian Style}

In setting Brundtland's two principal appearances on the world stage alongside one another it becomes possible to see how the Norwegian prime minister enacted a distinctive vision for humanitarian internationalism during the 1980s and 1990s. That vision took as its starting point the altruism of the Nordic brand but channelled this towards reform of the (then much less fully articulated) international scale in keeping with the tenets of what I have here described as the pragmatarian style. As the tensions inherent to the pragmatarian style played out, the redemptive intentions of Gro's leadership of the WCED and the WHO - to save the environment from economic growth and to save the world's health from the failures of the global health bureaucracy - were each ultimately subverted. But so too, along the way, was the kernel of a unique, even valiant, effort to democratize the international domain. Brundtland's primary concern to ensure that her prescriptions first secured the mobilizing force offered by the proponents of economic growth - that they become "effective" in this way - led the solutions devised at the WCED and the WHO to very often undercut the ends that had been intended. In the process, moreover, the political project of a social democratic vision for internationalism (a radicalism which focused on the need to democratize international policymaking, to incorporate the emergent power of social movements, and to maintain public accountability) lost out to a more "doable" set of solutions (the concept of sustainable development, the introduction of greater "efficiency" at the WHO) that could be sold to a narrower grouping of "stakeholders" and international elites.

If this reading in part explains the "lost" radicalism of the Brundtland Commission, equally it helps explain why Brundtland's reform program at the WHO was initially welcomed only to steadily become less popular among its more permanent staff. The reduction in Brundtland's political horizons, her move away from the utopianism of the era of the NIEO to her later more pro-market commitments of Third Way social democracy, are characteristic of the pragmatarian style. And here it is not merely Brundtland's contributions that need assessing; for such a reduction points as well to the costs of Norway's more general embrace of the pragmatarian style over recent decades in its approach to international 
development. In place of the paranoid style's future redolent with doomsday scenarios and precise and unwavering prophecies, adherents to the pragmatarian style see the future as always having somehow averted disaster. The pragmatarian future is populated by rights bearing citizens who have secured substantial advances at little or no cost to the present generation. It is filled with the statistical reward of the "lives saved," as at GAVI, or even of the life years gained, as with the Disability Adjusted Life Year (DALYs) and Quality Adjusted Life Year (QALYs) measures that became standard fixtures during Brundtland's time at the WHO and which her vision of calculable governance enhancements meshed so well with. It is as if the stakes, while millennial in the case of climate change, and tragic in the case of a global burden of disease gone unchecked, are somehow merely another externality effect awaiting to be properly priced. It is questionable, in light of this volume's consideration of the brand of the Scandinavian countries, whether this leaves Norway in fact anything like as distinctive as once it was.

It was not just "sustainable development" that proved to be a structural critique too easily defanged, in other words; or Brundtland's efforts to create a more vertical structure within the leadership of the WHO that proved to be an institutional reform too easily turned back to its prior reliance on the power of capital. The pragmatarian style of thinking that shaped Brundtland's (and to some extent Norway's) engagement with environmental and health politics in the late twentieth century, and which was mirrored in other leading countries (perhaps most notably Canada), was itself ultimately a way of "discussing" structural change without really undertaking it. In both cases Brundtland was, as a politician, successful to the extent that she brought two crucial issues environment and health - to the attention of powerful states and international actors. There can be little disputing this, whether one compares the impact of Rio (1992), which was born out of the WCED, to the legacy of the Stockholm conference (1972) that preceded it, or whether one compares the inadequate response to HIV/AIDS at the global scale prior to Brundtland's time at the helm of the WHO relative to after, not least in the formation of the Global Fund itself. Or indeed if one considers the more general rise in political attention to health spending in the wealthier nations during and after her tenure (such as the establishment of a health-related MDG in 2000; or the increased focus on international health within the G8 nations' own development ministries, for example). Yet in both cases that legacy has also been a mixed one. Perhaps via the pragmatarian style, in other words, we can 
begin to see just what it is that links Silicon Valley entrepreneurialism, philanthropy, and global governance policy elites of the sort that convene in Davos each year. Along the way, the altruism with which the Scandinavian brand is traditionally associated has been diluted by those aspects of the pragmatarian style that seek a return on its investments, and the political alloy that results is a complex and at times contradictory achievement: speaking still in the language of social democratic inclusion and compromise, while acting more often than not to reproduce the logic of a system that awakens humanitarian empathy in the first place.

\section{References}

de Bengy Puyvallée, A. (2018). Norway's Response to Ebola: Balancing Altruistic and Security Concerns. Internasjonal Politikk, 76(2), 89-120.

Borowy, I. (2013). The Brundtland Commission: Sustainable Development as a Health Issue. Michael Quarterly, 10(2), 198-208.

(2014). Defining Sustainable Development for Our Common Future. A History of the World Commission on Environment and Development. London: Routledge.

Brown, T., Cueto, M., \& Fee, E. (2006). The World Health Organization and the Transition from "International" to "Global" Public Health. American Journal of Public Health, 96(1), 62-72.

Brundtland, G. H. (1992). A Call for Environmental Action. Address to the Annual Meeting of the Harvard Alumni Association. The PSR Quarterly, 2(3), 161-164.

Brundtland, G. H. (2002). Madam Prime Minister: A Life in Power and Politics, Farrar, Straus and Giroux: New York.

Carruthers, D. (2001). From Opposition to Orthodoxy: The Remaking of Sustainable Development. Journal of Third World Studies, 18(2), 93-112.

Clift, C. (2013). The Role of the WHO in the International System. Chatham House Working Paper, Centre on Global Health Security. RIIA: London

Dalton-Bradford, M. (2000). Dramatiske år: 1986-1996: Review Essay. Scandinavian Studies, 72(1), 112-115.

Davies, S. E. (2010). Global Politics of Health. Cambridge: Polity Press.

Dierwechter, Y. (2018). The Urbanisation of Green Internationalism. London: Palgrave MacMillan.

Du Pisani, J. A. (2007). Sustainable Development: Historical Roots of the Concept. Environmental Sciences, 3(2), 83-96.

Ferguson, N., Maier, C. S., Manela, E., \& Sargent, D. (2010). The Shock of the Global: The 1970s in Perspective. Boston, MA: Harvard Belknap Press.

Gerasimova, K. (2017). An Analysis of the Brundtland Commission's Our Common Future. London: Routledge. 
Gibbs, N. (2001). Norway's Radical Daughter. Time Magazine, 24 June 2001.

Godlee, F. (1997). WHO Reform and Global Health: Radical Restructuring Is the Only Way Ahead. British Medical Journal, 314, 1359-1360, www.ncbi.nlm .nih.gov/pmc/articles/PMC2126641/pdf/9161300.pdf

Henderson, S. L. (2013). Gro Harlem Brundtland of Norway. In M. A. Genovese \& J. S. Steckenrider, eds., Women as Political Leaders: Studies in Gender and Governing. London: Routledge, pp. 43-80.

Hofstadter, R. (1964a). The Paranoid Style in American Politics and Other Essays. Boston, MA: Harvard University Press, November 1964.

(1964b). The Paranoid Style in American Politics. Harper's Magazine, November 1964.

Homedes, N. (1996). The Disability-Adjusted Life Year (DALY) Definition, Measurement and Potential Use. Human Capital Development Working Paper 68. Washington, DC. World Bank Group.

Lakoff, A. (2016). Unprepared: Global Health in a Time of Emergency. Berkeley: University of California Press.

Lerer, L. and Matzopoulos, R. (2001). The Worst of Both Worlds: The Management Reform of the World Health Organization. International Journal of Health Services, 31(2), 415-438.

Lidén, J. (2013). The Grand Decade for Global Health: 1998-2008. Chatham House Working Group on Governance, Paper 2. Available at: www .chathamhouse.org/sites/default/files/public/Research/Global\%20Health/ 0413_who.pdf

Linnerid, K. (2017). No Single Pathway to the Sustainable Development Space. Klima, 2017.

MacNeill, J. (1990). The Greening of International Relations. International Journal, 45(1), 1-35.

Melakopides, C. (1998). Pragmatic Idealism: Canadian Foreign Policy, 1945-1995. Montreal and Kingston: McGill-Queens University Press.

Moisio, S., Stokke, K., Sæther, E., Larsen, H. G., Ek, R., \& Hansen, A. L. (2011). Interventions in Nordic Political Geographies. Political Geography, 30, 241-249.

Montgomery, S. (2016). Environmentalist Jim MacNeill was an Early Warrior against Climate Change. Globe and Mail, 22 March.

New Internationalist (1992). “Whose Environment?”, Issue 232, June 1992.

O’Riordan, T. (1988). The Politics of Sustainability. In R. K. Turner, ed., Sustainable Environmental Management: Principles and Practice. London: Belhaven Press, pp. 29-50.

Pederson, J. (2005). Ideas, Think Tanks, Commissions and Global Politics. In R. Thakur, A. F. Cooper, \& J. English, eds., International Commissions and the Power of Ideas. Paris: United Nations University Press, pp. 266-276. 
Reid-Henry, S. (2017). From Welfare World to Global Poverty. Humanity Journal, 8(1), 207-226.

(2019). Empire of Democracy: The Remaking of the West Since the Cold War, 1971-2017. London: John Murray.

Ribberink, J. C. A. P. (2006). Gro Harlem Brundtland: A True Social Democrat. Social Europe Journal, Autumn, 72-77.

Ruger, J. P. (2005). Changing Role of the World Bank in Global Health. American Journal of Public Health, 95(1), 60-70.

Ruger, J. P. \& Yach, D. (2008). The Global Role of the World Health Organization. Global Health Governance, 2(2), 1-11.

Sachs, W. (2000) Planet Dialectics: Explorations in Environment and Development. London: Zed Books.

Slaughter, A. M. (1997). The Real New World Order. Foreign Affairs, 76(5), 183-197.

Smith, R. (1995). WHO: Change or Die. British Medical Journal, 310, 543-544, www.ncbi.nlm.nih.gov/pmc/articles/PMC2548932/pdf/bmj00582-0005.pdf

Smith, H. A. (2005). The World Commission on Environment and Development: Ideas and Institutions Intersect. In R. Thakur, A. F. Cooper, \& J. English, eds., International Commissions and the Power of Ideas. Paris: United Nations University Press, pp. 76-99.

(2005). The WHO: Change or Die. British Medical Journal, 310, 543.

Thacher, P. S. (1992). The Role of the United Nations. In A. Hurrell \& B. Kingsbury, eds., The International Politics of the Environment: Actors, Interests, and Institutions. Oxford: Oxford University Press, pp. 183-211.

Walt, G. (1993). WHO Under Stress: Implications for Health Policy. Health Policy, 24(2), 125-144.

World Commission on Environment and Development (WCED) (2009). Our Common Future (OCF). Oxford: Oxford University Press [1987].

(1988). Chronology of the Work of the World Commission. Available at https:// idl-bnc-idrc.dspacedirect.org/handle/10625/8942?show=full

Yach, D. \& Bettcher, D. (1998). The Globalization of Public Health, I: Threats and Opportunities. American Journal of Public Health, 88(5), 735-744.

Yamey, G. (2002). Interview with Gro Harlem Brundtland. British Medical Journal, 325(7376), 1355. 